\title{
UGT2B7 wt Allele
}

National Cancer Institute

\section{Source}

National Cancer Institute. UGT2B7 wt Allele. NCI Thesaurus. Code C105576.

Human UGT 2B7 wild-type allele is located in the vicinity of $4 q 13$ and is approximately 62 $\mathrm{kb}$ in length. This allele, which encodes UDP-glucuronosyltransferase 2B7 protein, is involved in regulating levels of estrogens and estradiols. 